\title{
Tourist competitiveness strategies, a proposal for the municipality of Huichapan, Hidalgo
}

\author{
Estrategias de competitividad turística, una propuesta para el Municipio de \\ Huichapan, Hidalgo
}

NAVA-SANTOS, Milton Alejandro†* \& PÉREZ-BRAVO, Julia

Universidad Autónoma de Querétaro, Cerro de las Campanas S / N, University Center, Querétaro, Qro. C.P. 76010, Mexico.

ID $1^{\text {st }}$ Author: Milton Alejandro, Nava-Santos / ORC ID: 0000-0002-9242-9351

ID $1^{\text {st }}$ Co-author: Julia, Pérez-Bravo / ORC ID: 0000-0002-1310-0145, Researcher ID Thomson: N-3319-2018, CVU CONACYT ID: 501992

DOI: $10.35429 / E J R P .2020 .11 .6 .18 .32$

Received July 15, 2020; Accepted December 30, 2020

\begin{abstract}
The purpose of this investigation was to know the current situation in terms of resources and tourist attractions of the Municipality of Huichapan Hidalgo, to determine the potential in this field and to propose the ideal strategies for tourist competitiveness that allow positioning this Magical Town as a Competitive municipality at the state level. The methodology used in the research was carried out under a mixed type and approach, likewise a hypothetical-deductive method, non-experimental cut, was used. Documentary, having carried out a theoretical investigation of the variables: Tourism, Strategies and Competitiveness, as well as the search for information in various documents created by governmental organizations for the determination of diagnoses, among which are the geographical-environmental and socio-economic, in addition to carrying out a list of the main tourist attractions, both natural and cultural; and field research: since unstructured interviews were applied to both the director of tourism and the chronicler of the municipality, which allowed to know the situation that the municipality is currently going through in terms of tourism competitiveness, as well as a structured questionnaire to the director of tourism in order to determine the tourism potential. Thus, then the results found were that the Magical Town of Huichapan is a destination with tourist potential that lacks complete or new tourist products where ignorance of the cultural and natural wealth, as well as the appropriate strategies for the destination does not favor the existence of tourist competitiveness, compared to four Magic Towns of the State of Hidalgo.
\end{abstract}

\begin{abstract}
Resumen
El propósito de esta investigación fue conocer la situación actual en materia de recursos y atractivos turísticos del Municipio de Huichapan Hidalgo, a efecto de determinar su potencial en este ramo y de proponer las estrategias idóneas de competitividad turística que permitan posicionar a este Pueblo Mágico como un Municipio competitivo a nivel estatal. La metodología utilizada en la investigación fue llevada a cabo bajo un tipo y enfoque mixto, así mismo se utilizó un método hipotético-deductivo, de corte no experimental. Documental, al haber realizado una investigación teórica de las variables: Turismo, Estrategias y Competitividad, así como a la búsqueda de información en diversos documentos creados por organizaciones de índole gubernamental para la determinación de diagnósticos, entre los que se encuentran el geográfico-ambiental y socioeconómico, además de la realización de una relación de los principales atractivos turísticos, tanto de tipo natural como cultural; e investigación de campo: puesto que se aplicaron entrevistas no estructuradas tanto a la directora de turismo y a la cronista del municipio, mismas que permitieron conocer la situación por la que atraviesa actualmente el Municipio en cuanto a competitividad turística, al igual que un cuestionario estructurado a la directora de turismo con la finalidad de determinar el potencial turístico. Así, entonces los resultados encontrados fueron que el pueblo Mágico de Huichapan es un destino con potencialidad turística que adolece de productos turísticos completos o novedosos en donde el desconocimiento de la riqueza cultural y natural, así como de las estrategias adecuadas para el destino no favorece la existencia de la competitividad turística, en comparación de cuatro Pueblos Mágicos del Estado de Hidalgo.
\end{abstract}

Turismo, Estrategias, Competitividad

Citation: NAVA-SANTOS, Milton Alejandro \& PÉREZ-BRAVO, Julia. Tourist competitiveness strategies, a proposal for the municipality of Huichapan, Hidalgo. ECORFAN Journal-Republic of Peru. 2020. 6-11:18-32.

\footnotetext{
* Correspondence to Author (Email: sanchez-usonmj@uaz.edu.mx)

$\dagger$ Researcher contributing first author.
} 


\section{Introduction}

The word competitiveness is a term that has been present since the beginning of time, since the ancient settlers already competed for food and for their survival. Likewise, competitiveness is a complex word to understand and difficult to measure due to the multiple facets that its meaning can have, since it is possible to identify that this word is used by a nation, a region, a municipality, a corporate or, a small business; and its purpose is to demonstrate the differentiating elements that have allowed it to obtain and improve a position in the incursion market.

Competitiveness in the world has generated a higher quality of life, so that people travel more and more and with this they have a greater tourist experience, they are more qualified and have a higher level of information regarding the destination. Therefore, tourist destinations, such as a Magic Town, must be able to increase the level of competitiveness in order to position themselves in the most appropriate way to meet the demands of the visitor or tourist.

In the present study carried out under a mixed type and approach and a hypothetical deductive method with a non-experimental cut, it is possible to answer the question: What is the tourist potential of the municipality of Huichapan and what strategies can be implemented to boost competitiveness? tourist in the Magic Town? It is aligned with the central objective of the research, being the following: To know the current situation in terms of resources and tourist attractions of the municipality of Huichapan, Hidalgo in order to determine its potential in this field and to propose the ideal competitiveness strategies tourism that allows positioning this Magic Town as a competitive municipality at the state level.

All of the above is possible thanks to the documentary search on the existing resources (natural, cultural and tourist) to conform them in a municipal diagnosis, as well as by field research by applying two unstructured interviews and a structured questionnaire, addressed to the director of tourism for the 20162020 administration and to the chronicler of Huichapan and honorary of the State of Querétaro. As well as by carrying out a theoretical search of the variables: Tourism, Strategies and Competitiveness.
The hypothesis proposed for the present work was: The public administration of the municipality of Huichapan, Hidalgo does not know what the tourist potential of the destination is, so no suitable strategies have been applied to promote the tourist competitiveness of the destination at the state level.

\section{Theoretical framework}

\section{Historical context of competitiveness}

According to Labarca, (2007) thanks to the reflections of economists after wanting to know the causes of why one country can dominate over another at a given moment, on the secret of superiority (generated by the control of the economy and the maximization of gold and silver) and on the strategies used to achieve it, allowed the issue of competitiveness to be addressed in a very subtle way; Adam Smith being the first to present a modern argument on the subject, as he believed that competition was important to achieve the maximization of efficiency that could be reflected in welfare.

Therefore, it was mentioned that countries should specialize and export those goods in which they had an absolute advantage and import those goods in which the trading partner was also, so then each country should export the goods that were produced with more efficiency as the absolute work required per unit would be less than that of the potential business partner.

Like Smith, David Ricardo collaborated to delimit the field of study of competitiveness and thus in 1817 through the work "Principles of political economy" the theory of comparative advantages was developed, which explained why a country could import goods while producing at low cost. (González \& Mendieta, 2018)

Later, in 1967, the theory of Jean-Jacques and Servan-Shreiberg arose, in which the challenges faced by European industries were exposed to the American ones, since the latter, being large and having access to world markets, had the possibility of producing at scale and developing technology; success that rested mainly on the novel and modern system of mass production, which was known and used throughout the world. 
Later in the seventies, with the incursion of Japanese companies in the western market, mainly that of automobiles and electronic articles, an interest arose in knowing the way in which these organizations operated, which were easy to produce a great variety of products without altering their costs, to adapt and improve their environment, for which Porter identified the mechanisms that determined competitiveness in the most successful industries in ten countries, which in turn led to their recognition as the greatest exponent in the area of business strategy.

Perez Bravo, (2012) citing the Economic Commission for Latin America and the Caribbean (ECLAC), mentions that the term competitiveness has its origin in the United States of America in the eighties, which was adopted to define the set of qualities that organizations and products associated with quality and internationality should have, as well as private companies. The foregoing led Mexico to implement development models based on the production of manufactured goods linked to the international market, which in turn favored that, in 1994, Mexico could sign the first free trade agreement with the United States of America and Canada to later sign with other countries.

In parallel, a strategy known as Industrial Reconversion was implemented, with the objective of carrying out a structural transformation of the economy; same that exposed the weaknesses and threats of companies that were not prepared to compete in the face of new international demands, rules and conditions.

\section{Defining competitiveness}

But then what is competitiveness?

The Royal Academy of the Spanish Language, (2017) [RAE], in the twenty-third edition of its dictionary of the Spanish language, provides two meanings to the word competitiveness:

- Ability to compete.

- Rivalry to achieve an end.
Labarca, (2007a) citing Ivancevich \& Lorenzi mentions that competitiveness is the extent to which a nation, under free and fair market conditions, is capable of producing goods and services that can successfully exceed the demands of international markets, maintaining and increasing at the same time, the real income of citizenship.

On the other hand, Díaz de Villegas, (2017) mentions that competitiveness is the capacity of an organization to efficiently use productive factors, in order to sustain and improve a certain socioeconomic position, influencing the way of raising and develop any business initiative, to evolve in the business growth and development model.

The term competitiveness can also be defined as the ability of a company to produce and sell products with better price, quality and opportunity conditions than its rivals, as stated (Narváez, Fernández, \& Senior, 2008).

Y; Based on Pérez, competitiveness is understood to be the capacity of a country, sector or organization to maintain and enter new markets, obtaining sustainable profits through products whose design, quality, marketing and price characteristics are better than those of their competition, making them key points for the success of the company in a globalized environment.

Thus, competitiveness is defined as the ability or skill that an organization has to demonstrate the elements that differentiate it from the rest by means of which it can obtain and improve a privileged position in the market in which it enters.

\section{Tourist Competitiveness}

Alcocer Lizcano, (2013) refers that tourism is a dynamic sector, which in recent decades has become the support of the national economy in many parts of the world, as it has successfully overcome enormous challenges and challenges demanded by globalization, the manner of consumption and the expectations of consumers. 
It should be noted that the interest in the knowledge of the factors that determine the competitiveness of tourist destinations have led to the existence of different conceptual models, which were proposed in the 90's, however the most prominent correspond to Geoffrey Crouch and Brent Ritchie who define tourism competitiveness as "The ability of a country to create added value and thus increase national well-being through the management of advantages and processes, attractions, aggressiveness and proximity, integrating the relationships between themselves in an economic and social model "(González \& Mendieta, 2009).

On the other hand, Alcocer, (2013a) proposes another definition where he refers that tourist competitiveness is the capacity of a destination to create and integrate products with added value that allow sustaining local resources and preserving its market position with respect to its competition.

Herce, (2017) establishes that the competitiveness of a tourist destination is determined from the competitive and comparative advantages that exist, since factors such as comparative advantages make a destination attractive to tourists such as natural tourist resources (climate, landscape , geographical location, flora and fauna) and cultural and human heritage (traditions, historical monuments or cultural legacy). Or some others such as competitive advantages that are strategies implemented by a destination to efficiently and sustainably manage its resources over time.

\section{Competitive strategy}

Competitive strategies are present in all organizations, they may not have been specifically designed through a planning process, but these can be implicit when being executed in the activities of the functional departments (Porter, 2015).

Fernández Lorenzo, (2019) based on Porter, mentions that a competitive strategy is one that has application when executing offensive or defensive actions in a given sector, and that with its implementation allows successfully facing the competitive environment and obtaining superior performance.
Competitive strategies are created to guarantee the following points (Garrido i Pavia, 2019a):

1. Offer sustainable profitability and meet the objectives set by the employer.

2. People within the organization must have the knowledge, skills and abilities necessary for the implementation of strategies.

3. It must be motivating for all areas of the organization.

4. Regardless of the size of the organization, the competitive strategy must be sustainable, profitable and durable against the competition.

Applicable strategies in tourism matters

In tourism, the strategy is the way forward to correlate tourism supply and demand, which in turn will allow decisions to be made to take advantage of the tourism offer in a conscious way, or to find an effective way to attract the desired tourist. to the destination, as long as you have the attention span.

Strategies in the field of tourism can be competitive, development or growth.

\section{Competitiveness strategy}

It is necessary to choose the appropriate route to be able to stand out from the immediate competition, where it is possible to resort to the following options:

1. Differentiation: The tourist offer must be authentic, unique, and attract the tourist by the symbolic elements of the destination.

2. Specialization: It is to adjust the tourist offer to the needs and preferences of the various types of tourists to be attracted.

3. Diversification: It consists of having a range of activities that can be directed to the different types of visitor or that are directed to a travel segment. 
Development strategy

It consists of guiding the development of tourism to get the most out of what is available, thus consolidating the tourist offer and assuming new challenges, by attracting new tourist segments. are:

The alternatives of this type of strategies

1. Consolidate the current tourism supply and demand: It is appropriate to apply it when a destination has not yet reached maturity and its tourism activity can still grow by taking advantage of its tourism resources, services and tourists.

2. Attract new tourists: Through this strategy it is possible to conquer new tourist demands through current tourists.

3. Create a new tourist offer: The services and resources of the destination can be elements that will have to be used to generate new tourist proposals.

4. Expand tourism supply and demand: It is to attract new tourists and create options of interest to tourists.

Growth strategy

Through this type of strategy, it is possible to make decisions regarding the quality of the service currently provided by the destination, as well as the installed capacity when attracting new tourists.

Therefore, the following complementary options are proposed:

Grow more: It is to expand the tourist offer or attract more tourists. The priority is quantity, because in a newly created destination what it requires is to attract tourists, or if it is a newly created destination to progress; hotels, infrastructure and visitors will be required.

Grow better: If what you are looking for is a better tourist offer or better tourists, quality is a priority. For example, if a destination is already underway, its priority will not be to attract tourists, but to improve the quality of the services offered, the training of personnel, and work to conserve resources.
Grow more and better: When both are key points that destiny requires. Normally, it is important for starting destinations, however, they could work on the implementation of sustainable tourism. For the good use of the tourist activity, it is necessary to work to increase the number of tourists, create new attractions or activities, as well as improve the tourist supply and demand with a conservation approach towards tourist resources and native peoples. (National Polytechnic Institute, 2018)

\section{Methodology}

For the development of the research, the methodology used was under a mixed type and approach, and through a hypothetical-deductive method of non-experimental cut.

Based on Zorrilla (1985), it is known that a mixed type investigation involves documentary and field research. In this case, documentary by having carried out a theoretical investigation of the variables: Tourism, Strategies and Competitiveness, and by searching for information in various documents created by governmental organizations for the realization of diagnoses, among which are the geographic- environmental and socio-economic, in addition to the creation of a list of the main tourist attractions, both natural and cultural; and direct or field research at the study site for the application of two unstructured interviews and a structured questionnaire.

On the other hand, this research has a mixed approach, because according to (Hernández Sampieri \& Fernández Collado, 2010) it involves the quantitative and qualitative approach that implies the collection and analysis of data to answer the research questions and test hypotheses made previously, relying on numerical measurement to accurately establish patterns of behavior in the population and data collection using techniques that do not intend to measure or associate measurements with numbers, unstructured observation, open interviews, document review, discussion being essential in group, evaluation of personal experiences, inspection of life histories or interaction of groups and communities. 
In the same way, the hypotheticaldeductive method of non-experimental cut-off has been used in this research, since a hypothesis has been proposed based on previous knowledge and the results derived from this have been respected as they have been presented in their context. natural.

For data collection, as point number one, two unstructured interviews were applied, defined by (Behar, 2008) as those interviews that have a more or less large margin with freedom to formulate the questions and answers.

It should be noted that the interviews had the purpose of knowing the situation that prevails in the Magical Town of Huichapan. The first interview (research instrument number 1) was applied to the director of tourism of Huichapan for the Administration 2016-2020, who also in the year 2013 to 2016 was a mediator in the museum of archeology and history of Huichapan, dependent on the Council State for Culture and the Arts of the State of Hidalgo. This same public official, by profession graduated in law, has extensive knowledge and skills in tourism, since she has participated in various courses and workshops related to tourism, among which are: "Creation of Night Tourism Products", " On-Site Visitor Attention during Tourist Tours ", " Digital Tourist Strategies ",“ Tourist Culture "“ Training of Tourist Informants ", among others, which have been given by the Hidalgo Unit Continuing Education Center of the National Polytechnic Institute and by the Secretary of Tourism of the State of Hidalgo, as well as by the Federal Secretary of Tourism.

On the other hand, to carry out the second interview, (second research instrument), it was necessary to go to the home of the municipal chronicler of Huichapan and honorary chronicler of the State of Querétaro, who says that, from a very young age when she was just beginning to reading was interested in learning about the history of Huichapan. And her appreciation and dedication have been so much in the historical research of the municipality that in 2010 she was co-author of the work "Independencia y Revolución Mexicana en el Estado de Hidalgo", an anthology that brings together a set of texts that they analyze in the Hidalgo environment two great scenes of struggles that led to the Mexico of today.
Both interviews were recorded using an electronic device to later reproduce the audio and transcribe the conversation as the conversation took place, thus allowing reflection on the responses.

And as step number two, it was also necessary to collect data through research instrument number three, called "Evaluation of Local Tourism Potential" prepared, validated and used in the investigations of municipalities of the country by the Federal Tourism Secretariat (SECTUR), that has allowed in a simple and orderly way, to compile the information of the evaluated site through five sections, which were answered carefully and objectively by the director of tourism in the municipality, a key person for this investigation due to her interaction with the tourist activity municipal, to later determine the tourism potential of Huichapan.

Each of the sections aimed to evaluate:

Section I-A Natural tourist resources

Section I-B Cultural tourism resources services

Section II Tourist equipment and

Section III Tourist facilities and services

Section IV-A General infrastructure and services

Section IV-A Tourism infrastructure and services

\section{Section V Tourist market}

Once the existence of resources, equipment, facilities, infrastructure and the arrival of tourists to the destination have been confirmed, the components of the tourism product are rated in a standardized way with the help of the following evaluation criteria.

\section{RED, YELLOW GREEN}

The red qualification means the absence of the natural or cultural resource, as well as the equipment, facilities, support infrastructure in the locality or tourist visits. 
Red rating $=0$ Yellow implies a strong deterioration, neglect, loss or contamination, as well as a high fragility and risk in natural and cultural resources or severe deficiencies and deficiencies in the services of equipment, facilities, and infrastructure that hinder the growth of tourism. likewise, the arrival of occasional or passing tourists.

Yellow rating $=1$ Green reflects that the natural or cultural resource, the equipment, the installation or the supporting infrastructure are in a position to be used for the development of the tourist activity, and the arrival of tourists specifically to the site under evaluation.

It should be noted that additionally a numerical value was assigned to each criterion (from 0 to 2 ) in order to establish a standardized measurement system for all the components that make up the tourism product, where the criterion of absence of supply or demand elements (red color) equals 0 ; The second criterion ensures the existence of the previous components, but in inappropriate conditions (yellow color) it is equivalent to 1 and the criterion that represents the components in acceptable conditions (green color) is assigned a value of 2 .

With the previous evaluation criteria, as well as the numerical value assigned in each case, it was possible to transform the qualitative measurement system into a quantitative one that made it possible to compare the components and elements that make up the tourism product.

Thanks to the numerical rating system, it was possible to add the values assigned for the component, as well as to average the ratings obtained in areas and sections, data that were useful for the evaluation of tourism potential.

This system only considers and evaluates the components that are scored when answering the questionnaire and the range of each score must be limited to values from 0 to 2 and be homogeneous for each concept analyzed.

Therefore, it is possible to express the values of the average total scores of each section of the questionnaire as follows:

RT $(0$ to 2$)=$ Total average rating of tourism resources.
EST $(0$ to 2$)=$ Total average rating of tourist equipment and services.

IST $(0$ to 2$)=$ Total average rating of tourist facilities and services.

IT $(0$ to 2$)=$ Total average rating of the tourist infrastructure.

$\mathrm{D}(0$ to 2$)=$ Total average rating of the demand for tourism services.

Finally, the total average value of the tourist offer of the municipality is determined, with the specific weights shown in the following table, in order to obtain a weighted average, giving greater importance to the existence of tourist resources in any region or municipality.

\begin{tabular}{|c|c|c|}
\hline Component & Value & $\mathrm{O}=0.4(\mathrm{RT})+0.2(\mathrm{EST})+$ \\
\hline $\begin{array}{l}\text { Tourist } \\
\text { resources } \\
(\mathrm{RT})\end{array}$ & 0.4 & $0.20($ IST $)+0.20($ IS $)$ \\
\hline $\begin{array}{l}\text { Tourist } \\
\text { equipment } \\
\text { and services } \\
\text { (EST) }\end{array}$ & 0.2 & \\
\hline $\begin{array}{l}\text { Tourist } \\
\text { facilities and } \\
\text { services } \\
\text { (IST) }\end{array}$ & 0.2 & \\
\hline $\begin{array}{l}\text { Infrastructure } \\
\text { (IS) }\end{array}$ & 0.2 & \\
\hline
\end{tabular}

Figure 1 Weighting Weights in the Tourist Offer Source: Own elaboration based on fascicle 8 of the Diploma material "Creation of Destination Tourist Products for Magical Towns

Where the total qualification of the demand (D) is the average value (arithmetic mean) of all the concepts that make up section $\mathrm{V}$ of the questionnaire; Each component of the demand has the same weight in the average, because it is necessary that the region or municipality under evaluation has a tourist influx, and consequently visitors must register a stay and an expense in the locality; and finally, the magnitude of the influx is the result of advertising and marketing activities.

The quantitative measurement system to qualify the components of a tourist product and its demand allowed to have a standardized frame of reference to evaluate the tourist potential of the municipality, which must be reflected on a Cartesian map with the help of coordinates, resulting from the total supply and demand ratings, as presented below: 


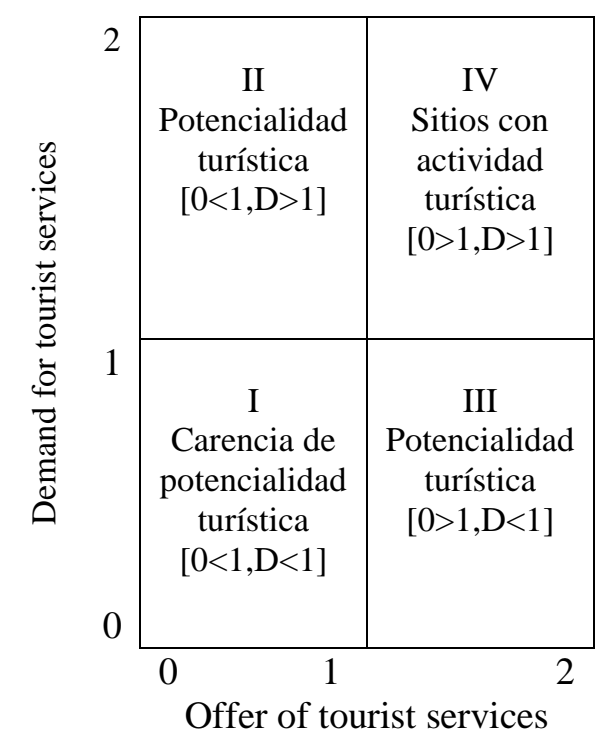

Figure 2 Tourist Potentiality Map

When locating the coordinates in the Cartesian plane, they will occupy one of the four quadrants assigned with a number and color: (Quadrant I, red color; Quadrant II and III, yellow color; Quadrant IV, green color) and interpretation that is presents below:

Quadrant I (Red color) The municipality whose average value of the supply is less than 1 and whose total average demand rating is less than 1. In other words, the study area lacks tourist products, has few natural resources or cultural, and / or lacks equipment, facilities, and tourist infrastructure. Likewise, there are no tourist visits or their arrival is sporadic. Therefore, every municipality located in quadrant I lacks sufficient tourist potential for the development of tourist activity, and an alternative productive vocation must be identified according to the strengths and opportunities of other economic activities.

Quadrant II and III (Yellow color) Municipalities that are characterized by having tourist potential, however, have a specific problem.

In the case of quadrant II, the average rating of the supply is less than 1 , but that of the demand exceeds the score, which means that the municipality lacks complete tourism products or activities and the tourism resources are in limited quantity or with severe deterioration, there are major deficiencies in equipment, facilities and tourism infrastructure.
Quadrant III (Yellow color) The average qualifications of the offer were higher than 1 and that, on the contrary, the value of the demand is less than one. In other words, the municipality under study has tourism products, resources, equipment, infrastructure and adequate facilities, but without sufficient tourist influx.

Quadrant IV (Green color) The regions and municipalities that are currently carrying out tourist activities are located; its average supply demand ratings exceed unity. Therefore, it is convenient to analyze the conditions of supply and demand to promote and strengthen its competitiveness.

\section{Results}

Thanks to the evaluation carried out in the Municipality of Huichapan Hidalgo, it was possible to identify that the intersection of supply (0.164) and demand (1.23) is located in quadrant number II in yellow, thus indicating that this destination has potential However, it does not have complete tourist products or activities that can be offered. On the other hand, tourism resources are in limited quantity or with severe deterioration and there are major deficiencies in tourism equipment, facilities, and infrastructure.

On the other hand, it was found that in the Municipality of Huichapan Hidalgo the activities and potential lines for the creation of tourist products should be planned, firstly, in accordance with traditional communities, secondly with mountain areas, thirdly with the monumental artistic heritage and as a fourth item the bodies of water.

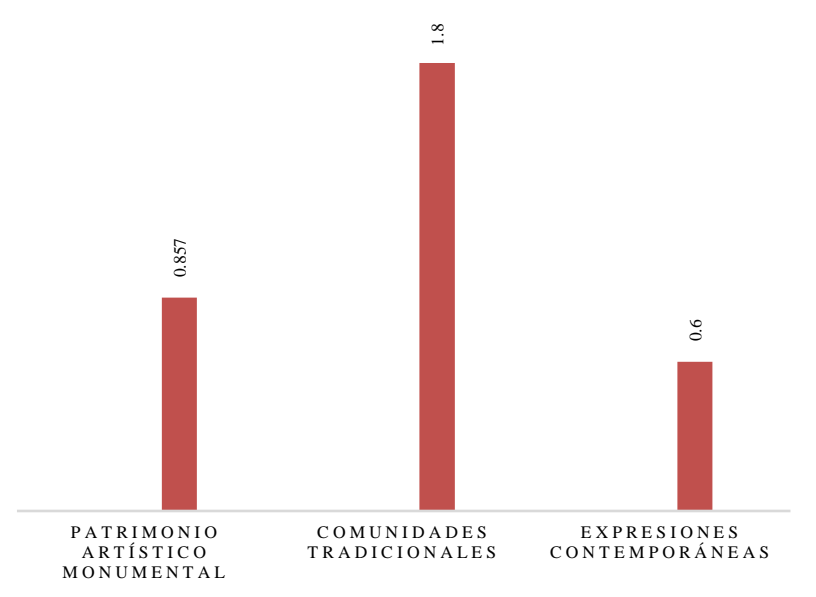

Figure 3 Cultural tourism resources Source: Own elaboration 


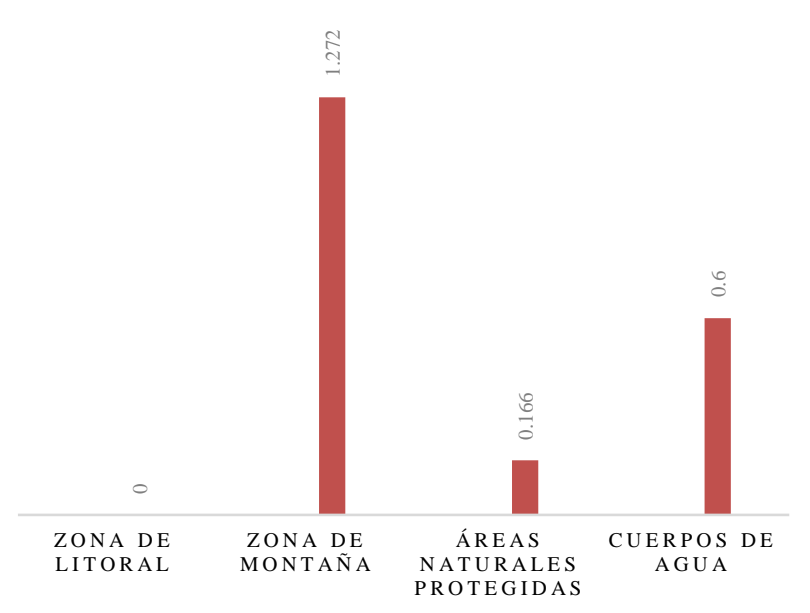

Figure 4 Natural tourist resources Source: Own elaboration

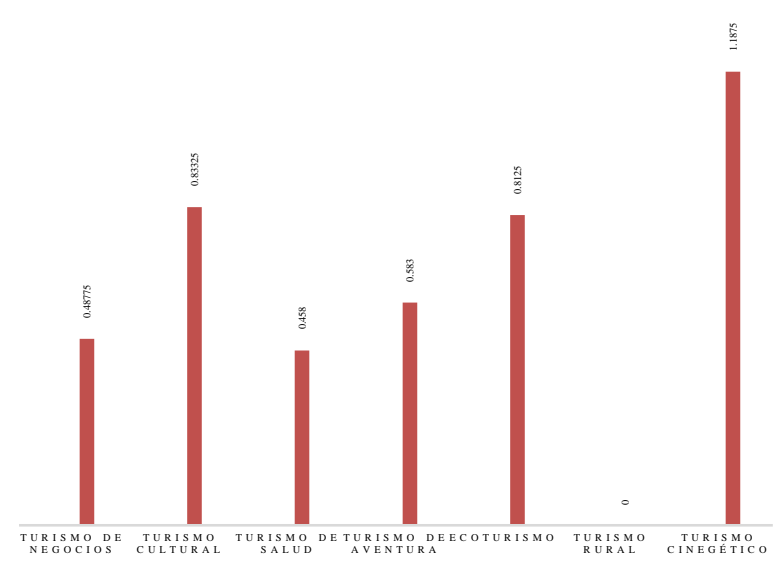

Figure 5 Tourist equipment and services Source: Own elaboration

Likewise, through the graph above, it is possible to know the potential lines of business that are identified in the municipality to enter into tourism competitiveness, taking into account the existing tourism equipment and services that favor activities. Thus, finding that in addition to cultural tourism (the only one consolidated in the municipality), it is necessary to bet on the creation of strategies to venture into hunting tourism and ecotourism.

On the other hand, the promotion of the destination through different means and the training of tourism service providers have been actions that the municipality has carried out to compete in tourism, however, at this time what the municipality requires are competitive strategies oriented to grow more and better, since it is important to increase the tourist plant to meet demand, since the insufficiency does not make it possible to attract more tourists.

\section{Conclusions}

At the end of this investigation, it is concluded that:

The development of tourist activity should be a priority issue for the municipalities; since tourism is an element that constitutes a source of income and prosperity for the population.

It is important to recognize that tourism planning plays a key role for the creation and implementation of strategies that favor the growth or permanence in the life cycle of a destination, in the case of Huichapan, competitiveness strategies will allow the revitalization of the destination and the future viability.

In the case of the municipality of Huichapan, it was relevant to know that it is currently a destination with tourist potential, because as mentioned in the development of this research, this Magic Town has a great variety of natural and cultural tourist resources, which They manage to attract tourists, however, there are no complete activities that make the tourist's stay more pleasant.

It is recommended that a program be implemented by the municipal public administration to manage the existing knowledge in the municipality regarding knowledge, languages, oral traditions, religious beliefs, cosmogony, uses, and customs that allow the preservation of tangible and intangible heritage, as well as strengthening tourism activity. Well, from all of the above, it is possible to create various tourist products that are of interest to tourists.

On the other hand, the activities and potential lines for the creation of tourist products in Huichapan have focused on a part of the cultural resources, thus preventing activities from being developed in traditional communities or in mountain areas, two of the items that more stand out through this analysis. And as for the potential lines of business in addition to cultural tourism, it is necessary to bet on the creation of strategies to venture into hunting tourism and ecotourism, duly regulated. 
It is suggested to work in a coordinated way with the organizations of the state or federal public administration for the evaluation of the Management Units for the conservation of Wildlife (UMAs) existing in the Municipality, which in turn will provide basic information to implement hunting tourism and ecotourism activities.

Implement sustainable tourism based on an analysis of the site with the support of sustainable development criteria.

The promotion of the destination through different means and the training of tourist service providers have been actions that the municipality has carried out to compete in tourism, however, it is also necessary to know the profile of the tourist so that the tourist products to offer, are designed according to your needs and based on the elements that already exist, which allow the realization of the tourist activity. Likewise, Huichapan requires strategies aimed at growing more and better.

Therefore, as a pending work in the future and derived from this research, it is suggested to carry out a study that allows to know the profile of the tourist who would like to visit Huichapan, having to direct assertive advertising campaigns. On the other hand, it is important to encourage entrepreneurship to create new spaces dedicated to hotels and food services, which can meet market demands.

Create alliances with the magical towns near Huichapan that allow offering innovative and value-added tourist products.

With the previous recommendation, the research work is concluded, hoping that these strategies can be implemented to achieve the tourist competitiveness of this destination.

\section{Discussion}

According to the findings in the investigation, it was learned that the Magic Town of Huichapan is a destination that, thanks to the variety of natural and cultural tourist resources, attracts tourists throughout the year, so its existence is indisputable. of its tourist potential.
Recognizing the above, the magazine (México Desconocido, 2013) pointed out that Huichapan is one of the most beautiful cities in central Mexico because in this municipality it is possible to walk through its cobbled streets, contemplate the monuments of the historic center, and enjoy its gastronomy or a thermal water spa that abounds in this region.

Likewise, the (Government of the State of Hidalgo, 2009) through the work "Historical Notes of Huichapan" released a wide period of the history of this magical town, which goes from its foundation to the early twentieth century, achieving recall the war of independence, the wars of intervention and reform where Huichapan was always present.

Thanks to all the great cultural and natural legacy, it is possible to develop tourism activity and above all to venture into the competitiveness of this sector, because as mentioned (Herce Diez, 2017) the competitiveness of a tourist destination is determined from the competitive and comparative advantages that exist, since factors such as comparative advantages make a destination attractive for tourists such as natural tourist resources (climate, landscape, geographical location, flora and fauna) and cultural and human heritage (traditions, historical monuments or cultural legacy).

On the other hand, (Alcocer Lizcano, 2009) mentioned that there are two groups of factors that affect tourist competitiveness, which are: resources and the environment or situational conditions.

Within the former are considered inherited resources (natural and cultural resources), created resources (tourist infrastructure that includes accommodation, transportation, restaurants, among others), and complementary factors or resources (general infrastructure of the destination, quality of service, hospitality, just to mention a few).

Huichapan, as a tourist destination, has deficiencies in the supply of complete tourist products or activities, as well as deficiencies in equipment, facilities, and tourist infrastructure. Indispensable to provide a competitive service to tourists and visitors. (García \& Siles, 2015) in the same sense, affirms that it is important to have a developed and diverse hotel industry. 
However, Pedro (2015) referred that the competitiveness of the tourism sector depends on the capacity of the industry to innovate and permanently improve the quality of the products offered.

Currently, the destination at this time to achieve competitiveness requires strategies aimed at growing more and better where growing more refers to expanding the tourist offer or attracting more tourists, while growing better allows improving the quality of the services offered, training of personnel, and working for the conservation of resources.

Thus then, Altimira \& Muñoz (2007) indicated that an adequate segmentation of demand, understanding their needs, preferences and the level of demand to satisfy their needs are elements that will allow the creation of competitive advantages in this sector.

In the case of Huichapan, the activities and potential lines for the creation of tourist products have focused solely on cultural resources, thus preventing activities from being carried out in mountain areas or in traditional communities, two of the areas that stood out the most. through this analysis of the data obtained. And as for the potential lines of business in addition to cultural tourism, it is necessary to bet on the creation of strategies to venture into hunting tourism and ecotourism.

In relation to the aforementioned Flores, Borborema \& Cristhoffoli (2016) indicated that community tourism arises as a means to alleviate poverty and provide an alternative source of income to community members, in addition to allowing income distribution through projects inclusive of a cultural, educational and health nature.

And with a different perspective (Coriolano, 2017) based on his research called Community tourism in the Brazilian Northeast, he mentioned that tourism, by settling in coastal communities, implementing their ventures, triggers confrontations between residents and the new promoters of spatial production that In turn, they unleash forms of real estate speculation in order to deploy their national hotels or resorts or international networks, where the strongest always has the greatest advantage, that is, the one with the greatest capacity to persuade.
On the other hand, the promotion of the destination through different means and the training of tourism service providers have been actions that the municipality has carried out to compete in tourism.

And as G. Novo E. de los Monteros, et al (2012) points out, renewal in tourism products requires to be communicated and announced so that consumers who have already been to the site return in search of new experiences. Where the text or images, objects, places or situations are not elements that give meaning to advertising but rather society itself that grants a symbolic value in terms of consumption and enjoyment.

\section{References}

Aceranza, M. A. (2006). Conceptualización, origen y evolución del turismo. México: Trillas. Acuña Delgado, Á. (2004). Aproximación conceptual al fenómeno turístico en la actualidad. Gazeta de antropología. Obtenido de http://digibug.ugr.es/bitstream/handle/10481/72 68/G20_17Angel_Acuna_Delgado.html?sequen ce $=9 \&$ isAll owed $=y$

Alcocer Lizcano, J. (2009). Competitividad en el sector turístico: una revisión de la literatura. Revista Lebret, 111-128.

Altimira Vega, R., \& Muñoz Vivas, X. (2007). El turismo como motor de crecimiento económico. Anuario económico y escurialense, 677-710.

Álvarez Calderón, J., Espinoza Villalba, J., Martínez Montero, C., \& Puga Costa, E. (2018). Desarrollo de la matríz Boston Consulting Group y su participación dentro del mercado: caso práctico empresa Apaysami RiobambaEcuador. Revista Caribeña de Ciencias Sociales.

Álvarez Jasso, M. (07 de 06 de 2018). La importancia del turismo internacional en México durante el periodo 2009-2014. Obtenido de http://oreon.dgbiblio.unam.mx/F/EBB53NHXQ MUVRVYPA4JSQH2KB892C5VF7JBIRJP18 PJ15F45H562172?func=full-setset\&set_number $=011712 \&$ set_entry $=000011 \& \mathrm{f}$ ormat $=999$

Ascotiaoffqueen. (13 de 07 de 2019). History of travel \& Tourism. Obtenido de http://www.ascotiaoffqueen.com/tourtravel/hist ory-of-travel-tourism/ 
Ávila Marcué, F. (2005). Tácticas para la negociación internacional: las diferencias culturales. México: Trillas.

Behar Rivero, D. (2008). Metodología de la Investigación. Shalom.

Berdugo Cotera, E. (2014). Competitividad: recorrido histórico, conceptos y enfoques recientes. Gestión \& Desarrollo, 175-182. Obtenido de https://revistas.lasalle.edu.co/index.php/gs/articl e/view/3334/2648

Bonilla, J. (15 de 07 de 2013). Nuevas Tendencias del Turismo y las Tecnologías de Información y las Comunicaciones. Obtenido de Anuario Turismo y Sociedad: https://revistas.uexternado.edu.co/index.php/tur soc/article/view/3713

Botero Pinzón, L. (2014). Internacionalización y competitividad. Revista ciencias estratégicas, 187-196. Obtenido de https://revistas.upb.edu.co/index.php/cienciases trategicas/article/view/4019

Cabrera Martínez, A., López López, P., \& Méndez, C. (2011). La Competitividad Empresarial: Un marco conceptual para su estudio. Documentos de investigación. Administración de empresas, 13-15. Obtenido de http://dx.doi.org/10.2139/ssrn.2016597

Castellanos, N., \& Cruz, P. (2014). Una mirada a la evolución histórica de la estrategia organizacional. Revista de Estudios Avanzados de liderazgo. Obtenido de regent.edu/real

Castellanos, O., Ramírez, D., Fúquene, A., Quintero, R., \& Fonseca, S. (2013). Competitividad, Apropiación y mecanismos para su fortalecimiento. Obtenido de https://www.researchgate.net/publication/30453 9371_Competitividad_apropiacion_y_mecanis mos_para_su_fortalecimiento

Castro Monge, E. (2010). Las estrategias competitivas y su importancia en la buena gestión de las empresas. Ciencias económicas, 247-276.

Contreras Sierra, E. R. (2015). El concepto de estrategia como fundamento de la planeación estratégica. Pensamiento y gestión, 152-181.
Coriolano, L. N. (2017). El turismo comunitario en el nordeste brasileño. Gestión Turística, 0820.

Corréa, Sugahara, \& Rodríguez. (2015). Estrategia Empresarial e innovación tecnológica de las industrias brasileñas. Invenio, 65-84.

De la Torre Padilla, O. (2012). Turismo: Actividad Mundial. México: Trillas.

Díaz de Villegas, J. A. (06 de 08 de 2017). El entorno macroeconómico y su influencia en la competitividad en el sector turismo en México. Obtenido de https://biblat.unam.mx/es/revista/xihmaipachuc a-hgo/articulo/el-entorno-macroeconomico-ysu-influencia-en-la-competitividad-en-elsectorturismo-en-mexico

Díaz Nieto, \& Contreras Medina. (08 de 06 de 2014). La gestión del conocimiento factor clave de competitividad. Obtenido de Un estudio de los modelos y paradigmas: www.eumed.net/ce/2014/2/conocimientocompetitividad.htm

Diéguez Castrillón, Gueimonde Canto, Sinde Cantorna, \& Blanco Cerradelo. (07 de 01 de 2019). Análisis de los principales modelos explicativos de la competitividad de los destinos turísticos en el marco de la sostenibilidad. Obtenido de www.uesc.br/revistas/culturaeturismo

Dirección General de Planeación y Proyectos de la SECTUR del Estado de Hidalgo. (2019). Compendio Estadístico 2018. Pachuca de Soto.

Duque Brito, A. (2010). Turismo y competitividad en Venezuela: una aproximación a la situación actual venezolana. Visión Gerencial, 133-150. Obtenido de http://erevistas.saber.ula.ve/index.php/visionger encial/article/view/933

Escuela Nacional de Hotelería. (06 de 06 de 2018). Introducción al turismo. Obtenido de http://enah.edu.ni/files/uploads/biblioteca/902.p df

Fernández Lorenzo, A. (08 de 01 de 2019). Conceptos de estrategia empresarial. Obtenido de api.eoi.es/api_v1_dev.php/fedora/asset/eoi:7810 0/componente78098.pdf 
Fernández Poncela, A. M. (07 de 01 de 2019). Una revisión del programa Puebos Mágicos. Obtenido de http://periodicos.uesc.br/

Flores e Silva, Y., Borborema Cunha, F., \& Christoffoli, A. (2016). Turismo Rural Comunitario. Gestión familiar y estrategias de consolidación en el Estado de Santa Catarina (Brasil). Estudios y perspectivas en turismo, 576-596.

García Hernández. (2008). Los determinantes de la competitividad nacional. Análisis y reflexiones a partir de un marco teórico conceptual. Obtenido de http://www.utm.mx/edi_anteriores/temas036/E NSAYO2-36.pdf

Garrido i Pavia, J. (08 de 01 de 2019). Las estrategias competitivas de las micro y pequeñas empresas detallistas ante la gran distribución. Obtenido de http://dialnet.unirioja.es/servlet/tesis?codigo $=77$ 897

Gobierno del Estado de Hidalgo. (2009). Apuntes Históricos de Huichapan. En G. d. Hidalgo, Apuntes Históricos de Huichapan (págs. 3-13). Pachuca de Soto, Hidalgo.

Gobierno Municipal de Huichapan. (22 de 10 de 2017). Plan Municipal de Desarrollo Huichapan. Obtenido de https://huichapan.gob.mx/planmunicipal-de-desarrollo/

Gobierno Municipal de Huichapan. (2018). Guía Turística: Huichapan Pueblo Mágico. Huichapan, Hidalgo.

González, R. C., \& Mendieta, M. D. (2009). Reflexiones sobre la conceptualización de la competitividad de destinos turísticos. Cuadernos de turismo, 111-128.

González, R., \& Mendieta, M. (2018). Reflexiones sobre la conceptualización de la competitividad de destinos turísticos. Revistas.um.es. Obtenido de en http://revistas.um.es/turismo/article/view/70201 $/ 0$
Guerrero González, P., \& Ramos Mendoza, J. (2004). Introducción al turismo. México: Patria. Guzmán, A., Mayo, A., \& Pérez, B. (15 de 07 de 2019). Patrimonio, Turismo, mueseología, investigación y mucho más. Obtenido de http://kaipachanews.blogspot.com/2016/06/turis mo-enfoque-global-por-andres.html

Guzmán, A., Mayo, A., \& Pérez, B. (12 de 07 de 2019). Turismo Enfoque Global. Obtenido de Turismo Enfoque Global: publicaciones.ujat.mx/cientificas/Documentos/.. ./Turismo\%20Enfoque\%20Global.pdf

Herce Diez, I. (08 de 08 de 2017). La Competitividad del Turismo Español. Obtenido de:

https://biblioteca.unirioja.es/tfe_e/TFE000946.p df

Hernández Sampieri, R., \& Fernández Collado, C. \&. (2010). Metodología de la investigación. México: Mc Graw Hill.

Huber Bernal, G., \& Mungaray Lagarda, A. (2017). Los índices de competitividad en México. Gestión y política pública, http://www.scielo.org.mx/scielo.php?script=sci _arttext\&pid=S1405-

10792017000100167\&lng=es\&tlng=es.

Ibáñez Pérez, R., \& Cabrera Villa, C. (2011). Teoría General del Turismo: un enfoque global y nacional. 31-35. Obtenido de http://uabcs.mx/difusion2017/files/libros/pdf/18 4_20160908023838.pdf

Instituto Nacional de Estadística y Geografía. (18 de 03 de 2009). Prontuario de información geográfica municipal de los Estados Unidos Mexicanos. Obtenido de http://www3.inegi.org.mx/contenidos/app/mexi cocifras/datos_geograficos/13/13029.pdf

Instituto Nacional de Estadística y Geografía. (2017). Anuario Estadístico y Geográfico de Hidalgo 2017. Obtenido de $\mathrm{http} / / /$ internet.contenidos.inegi.org.mx/contenid os/Productos/prod_serv/contenidos/espanol/bvi negi/productos/nueva_estruc/anuarios_2017/70 2825095093.pdf

Instituto Politécnico Nacional. (2018). Programa de transferencia tecnológica PROTT 2018. Diplomado Creación de Productos Turísticos de Destino para Pueblos Mágicos. México.

NAVA-SANTOS, Milton Alejandro \& PÉREZ-BRAVO, Julia. Tourist competitiveness strategies, a proposal for the municipality of Huichapan, Hidalgo. ECORFAN Journal-Republic of Peru. 2020 
Jiménez Baños, P., \& Aquino Jiménez, F. K. (2012). Propuesta de un modelo de competitividad de destinos turísticos. Estudios y perspectivas en turismo, 977-995. Obtenido de http://www.scielo.org.ar/scielo.php?script=sci_ arttext\&pid=S185117322012000400010\&lng=e s\&tlng=es

Koontz, H., Weihrich, H., \& Cannice, M. (2012). Administración una perspectiva global y empresarial. México: Mc Graw- Hill.

Labarca, N. (2007). Consideraciones teóricas de la competitividad empresarial. Omnia. Obtenido de

:<http://www.redalyc.org/articulo.oa?id=73713 208> ISSN 1315-8856

Linás, F. (1997). Competitividad internacional y estratégica de las empresas colombianas. Gestión 3, 1-23.

Madrid Flores, F. (2013). La gobernanza en turismo como un factor para alcanzar destinos turísticos exitosos: El caso de los Pueblos Mágicos de México. Obtenido de https://dialnet.unirioja.es/servlet/tesis?codigo=1 18777

México Desconocido. (2013). Huichapan Pueblo Mágico. Obtenido de Huichapan Pueblo Mágico:

https://www.mexicodesconocido.com.mx/huich apan-hidalgo-pueblos-magicos-mexico.html

Morillo Moreno, M. C. (2011). Turismo y producto turístico. Evolución, conceptos, componentes y clasificación. Visión Gerencial. Obtenido de http://www.redalyc.org/articulo.oa? $\mathrm{id}=4655458$ 90011> ISSN 1317-8822

Narváez, M., Fernández, G., \& Senior, A. (2008). Aproximación al análisis de competitividad sistémica en el contexto del sector petroquímico de Paraguaná. Multiciencias $2017 . \quad$ Obtenido de http://www.redalyc.org/articulo.oa?id=9041169 1008

Novo E. de los Monteros, G., Osorio García, M., Torres Nafarrete, J., \& Esquivel Solís , E. (2012). Imagen turística y medios de comunicación, una construcción social. Estudios y perspectivas en turismo, 1409-1432.
Olivo de Alba, G. (2006). Revisión Histórica del Turismo en México. Cuaderno 14. Planeando sobre el Turismo Cultural, 34-43.

Organización Mundial del Turismo. (07 de 06 de 2018). Glosario básico. Obtenido de media.unwto.org/es/content/entender-elturismo-glosario-basico

Pascarella, R., \& Fontes, J. (2010). Competitividad de los destinos turísticos. Modelo de evaluación basado en las capacidades dinámicas y sus implicancias en las políticas públicas. Estudios y perspectivas en turismo, 117.

Perez Bravo, J. (2012). La gestión del conocimiento como factor de la competitividad en las pymes del sector restaurantero del Estado de Querétaro. Obtenido de http://ri.uaq.mx/handle/123456789/2601

Pérez Ramírez, C. A., \& Antolín Espinoza, D. I. (2016). Programa pueblos mágicos y desarrollo local: actores, dimensiones y perspectivas en El Oro, México. Revista de alimentación contemporánea y desarrollo regional, 218-242.

Porter, M. E. (2015). Estrategia competitiva. Técnicas para el análisis de los sectores industriales y de la competencia. México: Grupo Patria.

Real Academia de la Lengua Española. (06 de 08 de 2017). Real Academia de la Lengua Española. Obtenido de http://dle.rae.es/?id=A0rd5WL

Recorri2, R. (2019). Tecozautla un pueblo mágico de Hidalgo en México. Obtenido de https://www.recorri2.com/destinos-pordescubrir/hidalgo/tecozautla-un-pueblomagico-de-hidalgo-en-mexico

Saavedra García, M. L. (06 de 08 de 2017). Una propuesta para la determinación de la competitividad en la pyme latinoamericana. Obtenido de http://www.redalyc.org/articulo.oa?id=6462486 7005

Secretaría de Turismo. (2014). Obtenido de Pueblos http://www.sectur.gob.mx/gobmx/pueblosmagicos/huichapan-hidalgo/ 
Sectur. (25 de 01 de 2017). Lineamientos generales para la incorporación y permanencia al programa Pueblos Mágicos. Obtenido de https://www.gob.mx/sectur/documentos/lineami entos-generales-para-la-incorporacion-ypermanencia-al-programa-pueblos-magicos

Sectur. (07 de 06 de 2018). Glosario. Obtenido de

https://www.datatur.sectur.gob.mx/SitePages/G losario.aspx

Sectur. (19 de 10 de 2018). Identificación de Potencialidades Turísticas en Regiones y Municipios. Obtenido de https://gestiondedestinos.files.wordpress.com/2 011/11/fasciculo81.pdf

Shaadi, R., Pulido, J., \& Rodríguez, I. (2017). El Producto Turístico en los Pueblos Mágicos de México. Un análisis crítico de sus componentes. Revista de Estudios Regionales, 125-163.

Ubfal, D. (07 de 08 de 2017). Competitividad y desarrollo de la economía argentina. Obtenido de

www.economicas.uba.ar/wpcontent/uploads/20 16/03/CENES15.pdf.

Universidad Autónoma de Querétaro. (19 de 03 de 2019). Guía para la escritura de tesis de posgrado en la Universidad Autónoma de Querétaro. Obtenido de http://dip.uaq.mx/index.php/cposgrado

Metropolitana, (17 de 03 de 2019). Guía a la redacción en el estilo APA, 6ta edición. Obtenido de https://www.ubu.es/sites/default/files/portal_pa ge/files/guia_estilo_apa.pdf

Valverde, C., \& Benavides, M. (2017). El turismo en México, una visión hacia el futuro. Planur-e, 1-15.

Van der Horst Álvarez, A. (2006). Competitividad, Desafío Global para el Reto Local, Caso dominicano. Obtenido de https://issuu.com/cncrd/docs/competitividad.

Velázquez García, M. (2013). La formulación de las políticas públicas de turismo en México. El caso del programa federal " Pueblos Mágicos" 2001-2012. Diálogos latinoamericanos, 89-110.
Viloria Cedeno, N. (06 de 06 de 2018). Desarrollo turístico y su relación con el transporte. Obtenido de http://www.redalyc.org/articulo.oa?id=2233242 04002> ISSN 0717-1811

www.gob.mx. (06 de 06 de 2018). Obtenido de https://www.gob.mx/se\%7Cmexicocompetitivo /acciones-y-programas/indice-

decompetitividad-mundial-instituto-para-eldesarrollo-gerencial-imd recuperado

Zazueta López, D. (07 de 06 de 2011). La contribución del turismo al crecimiento económico. Obtenido de http://ri.uaq.mx/bitstream/123456789/6454/1/R I002361.pdf

Zorrilla, S. (1985). Introducción a la metodología de la investigación. México: Océano. 